\title{
Electronic mobility aids for persons who are visually impaired
}

Citation for published version (APA):

Roentgen, U. R. (2013). Electronic mobility aids for persons who are visually impaired. [Doctoral Thesis, Maastricht University]. Universitaire Pers Maastricht. https://doi.org/10.26481/dis.20130307ur

Document status and date:

Published: 01/01/2013

DOI:

10.26481/dis.20130307ur

Document Version:

Publisher's PDF, also known as Version of record

\section{Please check the document version of this publication:}

- A submitted manuscript is the version of the article upon submission and before peer-review. There can be important differences between the submitted version and the official published version of record.

People interested in the research are advised to contact the author for the final version of the publication, or visit the DOI to the publisher's website.

- The final author version and the galley proof are versions of the publication after peer review.

- The final published version features the final layout of the paper including the volume, issue and page numbers.

Link to publication

\footnotetext{
General rights rights.

- You may freely distribute the URL identifying the publication in the public portal. please follow below link for the End User Agreement:

www.umlib.nl/taverne-license

Take down policy

If you believe that this document breaches copyright please contact us at:

repository@maastrichtuniversity.nl

providing details and we will investigate your claim.
}

Copyright and moral rights for the publications made accessible in the public portal are retained by the authors and/or other copyright owners and it is a condition of accessing publications that users recognise and abide by the legal requirements associated with these

- Users may download and print one copy of any publication from the public portal for the purpose of private study or research.

- You may not further distribute the material or use it for any profit-making activity or commercial gain

If the publication is distributed under the terms of Article $25 \mathrm{fa}$ of the Dutch Copyright Act, indicated by the "Taverne" license above, 
(1)

\section{Summary}

(9)

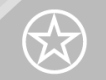

(1)

(wc) 
Since the 1960s, Electronic Mobility Aids (EMA) have become commercially available to assist persons who are visually impaired in obstacle avoidance, landmark detection and spatial orientation, based on acoustic or optic sensing of the environment. The history of the development of EMA has been paralleled by examinations of them focusing on various technical and design issues, e.g. the kind and amount of information provided and the way in which this is done, and also on their use and their impact on mobility. A study of EMA that are available today was prompted by the following reasons.

1. Due to demographic trends in Western societies, the population is ageing and the number of persons who are visually impaired is expected to increase.

2. With the advent of the Global Positioning System (GPS) in the 1990s in combination with Geographic Information Systems (GIS), a new kind of EMA evolved to support wayfinding by making map content accessible and by providing route guidance and information on users' current position and vicinity.

3. Fast technological advancements in the mainstream consumer market domain have benefited Assistive Technology Devices (ATD) such as EMA, improving their capacity, and reducing their size, weight and costs. Already apparent before the start of this study these advancements are still ongoing.

Despite their promising potential and the rapid improvements in technology as outlined above, EMA are not widely used nor do they form an inherent part of the orientation and mobility (O\&M) instruction and curriculum. A gap in knowledge on (available) devices, their functional abilities, as well as their effects on mobility and participation was identified.

The objective of this thesis was threefold: first, to describe the available EMA in technical and functional terms and to systematically review the evidence on their effects; second, to assess the functionality and usability of different devices; and third, to establish a method to investigate the effects of EMA category 2 on mobility and participation.

In Chapter 1 critical aspects of the mobility of persons who are visually impaired are described. The main processes of this mobility - obstacle detection, landmark identification, spatial and geographical orientation - serve as a framework for the categorization of supports and assistive devices which visually impaired persons can use to foster independent outdoor mobility. An explanation of which kind of technologybased devices come under the umbrella term EMA, and how EMA are defined and categorized in this thesis, is placed within the broader context of common mobility and orientation aids. Long cane, dog guides and conventional orientation aids are briefly introduced, and their main functionality and limitations are addressed. Subsequent to the definition and prevalence of visual impairment and a summary of 
major causes and consequences, the objectives, research questions and outline of the thesis are delineated.

Chapter 2 reports on an extensive literature and internet search, conducted to gain insight into the state of the art of EMA. In total, 146 systems and products, including those which are no longer available and those which are at developmental stage, were systematically described following a standard structure. Commercially available products for individual use not based on environmental adaptations were further classified into EMA category 1 (devices aimed at obstacle detection and orientation) and EMA category 2 (navigation systems). Thirteen products in the first category and ten in the second category were further specified by the devices' main intended functionalities, components, interface (in- and output modalities), and technical specifications. For EMA category 1, the device's range of detection, handling and mounting were additionally detailed; for category 2 devices, different modes of travel, kinds of information provided and possible (ways to create) routes were listed. A variety in features and a range in the complexity of function was ascertained within both categories.

Chapter 3 presents the method and results of a systematic review which was performed to reveal the effects and effectiveness of EMA as described in the international literature. Thirteen studies on 6 different EMA available at that time were included. Two studies addressed one of the ten navigation systems identified (EMA category 2). The remaining 11 studies evaluated five of the 13 available category 1 devices for obstacle detection and orientation. Eight studies used an experimental within-subjects (repeated measures) design or a single subject alternating treatment design, while the design of the others was referred to as a field trial, survey and a follow-up study. In the majority of studies, positive effects of the use of EMA were found. The navigation system demonstrated significant improvement in the ability to determine and reach defined destinations in experimental and real-life settings. Four studies on EMA category 1 which assessed mobility performance with an experimental design found an increased ability to avoid obstacles and detect landmarks, or enhanced travel skills; those three which also measured speed of travel found this to be decreased. In one study walking speed increased due to a higher amount of preview. Another study found no impact on mobility performance. Most participants perceived their travel to be safer, more comfortable and less stressful, which was also found to be true for EMA users in the surveys and the follow-up study. Reported percentages of continued use ranged from $44 \%$ to $100 \%$; the quality and amount of travel increased for the majority of users. Reasons for non-use were not associated with the devices' functionality, but with their design, users' personal or environmental circumstances or familiarization with the environment in which they travelled. 
The development of an indoor mobility course for the assessment of mobility performance as part of a user evaluation of EMA is described in Chapter 4. A literature search led to an inventory of previously used study designs for mobility assessment of the target group, critical factors and determining elements for the assessment of mobility performance and for the structure of a mobility course which can serve as a tool when designing a future mobility course. Based upon this inventory, concrete choices were made for the intended user evaluation, which were guided by the devices selected and their functionalities in order to contrast these to those of the long cane, as well as by representative tasks and practical considerations. As a result, a quasi-experimental design was chosen to ascertain participants' mobility performance in an indoor, well-controlled environment in terms of the time needed to complete a standardized course with 21 obstacles, Percentage Preferred Walking Speed (PPWS), and type and frequency of occurrence of nine previously defined mobility incidents. A trial version of the mobility course was set up and pilot tested, and expert advice from O\&M specialists confirmed its content and face validity. Applied within the user evaluation, the described measurement method was found to be feasible and sufficiently sensitive to assess differences in mobility performance when using an EMA compared to the regular mobility aid.

To gain insight into the usability and functionality of EMA and their effects on mobility, six systematically selected EMA were assessed in a user evaluation.

In the first round, eight persons who are visually impaired evaluated two EMA aimed at obstacle detection and orientation (Chapter 5) on a standardized indoor mobility course, which is depicted in chapter 4 . Changes in mobility performance were observed with both EMA. The PPWS decreased significantly when using the UltraCane (UC) $(38.36 \% \pm 7.72)$ compared to the long cane $(48.74 \% \pm 6.72)$. Participants also walked more slowly when using the Miniguide (MG) in conjunction with their regular mobility aid $(41.21 \% \pm 12.22)$, although not significantly. The number of mobility incidents decreased from $18.4 \pm 5.7$ to $10.2 \pm 4.2$ (UC) and $8.5 \pm 3.9$ (MG) respectively, and this was significant for both EMA. Participants made fewer contacts with the cane and with the body, explored the surroundings less with hands and feet, and interventions of the O\&M specialist were less frequently necessary, whereas abrupt changes in walking speed occurred more often when an EMA was used. Most participants were generally quite satisfied with the EMA as ascertained by the D-QUEST. No significant difference on the total score on user satisfaction between the UC and the MG was found on group level; however some respondents expressed a marked preference for one of the devices. Participants detailed advantageous as well as disadvantageous aspects, and the additional comments concerning the functionality and certain features of both devices indicated that individual user's characteristics and preferences, and factors such as their regularly used cane 
technique, additional impairments and (the duration of) training and familiarization play an important role in the devices' appraisal.

In the second round (Chapter 6) four EMA aimed at navigation - BrailleNote GPS, Trekker, Trekker Breeze and Wayfinder Access - were evaluated by 18 persons who are visually impaired. Eleven tasks that had been selected to provide sound insight into the operation and functionality of the devices, were first used for instruction and training and served as test situations afterwards. An essential part was travelling an unfamiliar outdoor route.

Execution times on the tasks performed showed a high inter-subject variability. All tested functionalities were judged at a higher-than-satisfactory level with one exception. Two devices' "Explore route in advance" and "Where am I?" functions were rated best. Mean ratings for all the tested functionalities based on Dutch school grades ranged from 7.2 to 8 , individual scores per device from 6.2 to 9.9. The response on seven items of the D-QUEST showed that user satisfaction was better than more-or-less-satisfied for all but two aspects of one device; overall scores on group level ranged from 3.3 to 4.2 per device whereas individual total scores ranged from 2.3 to the maximum score of 5 . Participants' additional comments and the experimenter's observation were analyzed and showed distinct individual preferences concerning e.g. input, data entry, quantity and detail of the provided information. Regarding route following, with every device, some users stated that they felt (very) safe while others, who did not feel safe with route guidance by the devices alone, judged the information provided as insufficient to travel an unknown route independently. Participant's "readiness" for use in terms of orientation and mobility skills, and prior experiences in independent travel applying other techniques for orientation were decisive for the evaluation of the navigation systems.

The findings of both rounds of user evaluations emphasize the importance of careful consideration of individual needs and wishes, user's goals and expectations regarding the functionality of EMA for the advisory process and the selection of a suitable device that represents a good match between human- and product-related intended use.

Chapter 7 reports on the development of a guideline to support the advisory process of EMA category 2, based on the results of the first two phases of this study. To this end, four steps of a general Dutch prescription guideline for the provision of AT, the 'RiFA', have been specified for three currently available navigation systems: Trekker Breeze, Kapten Mobility and the iPhone with a combination of navigation apps. A set of 15 forms and four documents accompanied by detailed explanations of the procedure to be followed has been compiled, which establish a systematic approach for identifying the problem and request for care, goal-setting, program of requirements and product selection. They were linked to an EMA database that ensures comparability of different products by a standardized way of describing 
them in-depth in functional and technical terms. Together with a protocol for training and a method for the evaluation of the effectiveness of the AT provision, the protocol developed is implemented at the Dutch care providers Bartiméus and Royal Visio. Both protocols are embedded into the curriculum for continuing education of orientation and mobility specialists. A web-based information product on EMA for different target groups is being compiled.

Chapter 8 presents a method to measure factual outdoor mobility and travel behaviour as part of the outcome assessment of long-term use of EMA category 2 (navigation systems). Pre-structured, accessible format activity diaries (AD) were combined with GPS data loggers (DL). Both parts ascertain the total number of trips and the number of trips made walking. The AD allows for further specification of the mode of travel, travel purpose, support and assistive devices used, familiarity with the route, emotional state during travel and whether persons travelled independently or aided. The DL provides more objective data on the elapsed time, total distance covered, average travel speed, and the maximum-, start- and end-distance from home. A tailored software application left the location component of the logged data unaccounted, enabled easy and straightforward data analysis, and ensured participants' privacy. A total of 53 visually impaired persons completed the 14-day measurement period, which corresponds to a response rate of $79.1 \%$. The mean total number of trips was $70.70 \pm 33.5$ (AD) and $66.85 \pm 27.26$ (DL) respectively, and most trips were made by walking ( $63 \% \mathrm{AD}, 51 \% \mathrm{DL}$ ), followed by $18 \%$ as a passenger in a car, and $14 \%$ using public transportation. Nearly one-quarter of all trips were performed for the purpose of transportation, $17 \%$ for (recreational) walking (the dog), and nearly $12 \%$ for IADL. Three-quarters of all trips covered a standard or familiar route. In sum, $61 \%$ of all trips were made independently. On average, owners of a dog guide made more trips than long cane users, followed by participants who used a symbol (identification) cane and those who did not use any mobility aid. The mean total distance covered by walking was $25.58 \pm 20.03 \mathrm{~km}$, whilst $394.49 \pm$ $336.9 \mathrm{~km}$ were covered by other modes of transportation. Correlation and agreement on those aspects which both instruments measured was fair. Data collection and analysis proved feasible and the method enables effectiveness research on EMA.

Chapter 9 contains the main findings of the study. They are discussed against the background of theoretical and methodological considerations, and implications for practice are presented. A major part of the implications for practice could already be realized through an implementation project. Based on the results of the first two phases of this study, which revealed points of particular interest deserving consideration in the process of EMA provision, a clinical practice guideline for the selection and advisory process has been developed, and it has been possible to conceptualize 
accessible, tailored information on EMA for users, professionals and other stakeholders. The systematic approach for the specification of all steps in the process of service delivery in accordance with RiFA should be applied to other categories of mobility-related and other AT devices for persons who are visually impaired. Further research addresses the execution of a long-term use effectiveness study following the method described in chapter 8 in the design of a randomized controlled trial. 



\section{Samenvatting}

(9)

(1) 
Elektronische Mobiliteitshulpmiddelen (EMA) zijn commercieel verkrijgbaar sinds de jaren 1960. Zij kunnen mensen met een visuele beperking ondersteunen bij het vermijden van obstakels, het vinden van herkenningspunten en bij de ruimtelijke oriëntatie door het verkennen van de omgeving met behulp van akoestische of optische signalen. Parallel aan de ontwikkeling van EMA heeft onderzoek plaatsgevonden, gericht op verschillende technische aspecten en het ontwerp van EMA, zoals het soort en de hoeveelheid verstrekte informatie en de manier waarop deze informatie aangeboden wordt, maar ook naar het gebruik en de effecten op mobiliteit. De volgende redenen vormden de aanleiding om een studie te verrichten naar EMA die tegenwoordig verkrijgbaar zijn.

1. Op grond van de demografische ontwikkelingen in Westerse samenlevingen is er sprake van vergrijzing en wordt verwacht dat het aantal mensen met een visuele beperking zal toenemen.

2. Met de opkomst van het 'Global Positioning System' (GPS) in de jaren 1990 kon in combinatie met 'Geographic Information Systems' (GIS) een nieuwe categorie EMA ontstaan. Deze EMA ondersteunen de gebruiker bij navigatie en het vinden van de weg, zij maken kaartmateriaal toegankelijk, bieden routebegeleiding, informatie over de actuele positie van de gebruiker en over zijn omgeving.

3. Snelle technologische ontwikkelingen op het gebied van de gewone consumentenproducten zijn ook bevorderlijk voor hulpmiddelen zoals EMA, omdat zij de functionele capaciteiten verbeteren, tot een vermindering in grootte en gewicht en tot lagere kosten leiden. Deze ontwikkelingen werden reeds voor de start van de studie zichtbaar en zijn nog steeds gaande.

Ondanks hun veelbelovend potentieel en de continue verbeteringen in de technologie zoals hierboven uitgelegd, worden EMA nog niet veel gebruikt. EMA instructie en training maken nog niet standaard deel uit van de oriëntatie- en mobiliteits(O\&M) training en van het leerplan voor O\&M instructeurs. Een gebrek aan kennis over (het aanbod van) beschikbare producten, de functionele mogelijkheden die EMA bieden en hun effecten op de mobiliteit en participatie van gebruikers was aanleiding voor deze studie.

De doelstelling van de studie was drieledig: ten eerste, het beschrijven van verkrijgbare EMA in technische en functionele termen en het systematisch in kaart brengen van het wetenschappelijk bewijs van de effecten van EMA, ten tweede het verkrijgen van inzicht in de functionaliteit en bruikbaarheid van verschillende EMA en ten derde, het opstellen van een methode om de effecten van EMA categorie 2 op mobiliteit en participatie te kunnen onderzoeken.

In Hoofdstuk 1 worden de kritieke aspecten in de mobiliteit van personen met een visuele beperking beschreven. De vier belangrijkste onderdelen: obstakeldetectie, het identificeren van herkenningspunten, ruimtelijke en geografische oriëntatie 
dienen als een kader voor het categoriseren van de verschillende soorten ondersteuning en hulpmiddelen die mensen met een visuele beperking kunnen gebruiken om zich zelfstandig buitenshuis te verplaatsen. Er wordt uitgelegd welke technologische hulpmiddelen onder de overkoepelende term EMA vallen en hoe EMA in deze thesis gedefinieerd worden. Daarnaast wordt aangegeven hoe EMA geplaatst kunnen worden in de context van gewone mobiliteitshulpmiddelen en hulpmiddelen voor oriëntatie. Taststok, geleidehond en traditionele oriëntatiehulpmiddelen worden kort beschreven, waarbij tevens hun meest belangrijke functionaliteiten en tekortkomingen aan bod komen. Naast de definitie en prevalentie van visuele beperkingen worden de meest voorkomende oorzaken en gevolgen van visuele beperkingen samengevat. Vervolgens worden de doelstellingen en onderzoeksvragen van de thesis gepresenteerd. Het hoofdstuk eindigt met een leeswijzer.

Hoofdstuk 2 beschrijft een uitgebreid literatuuronderzoek en Internet search die verricht zijn om inzicht te verkrijgen in de huidige stand van zaken van EMA. In totaal zijn 146 systemen en producten (waaronder hulpmiddelen die niet meer beschikbaar zijn en prototypes) systematisch volgens een gestandaardiseerde structuur beschreven. Commercieel verkrijgbare producten die individueel gebruikt kunnen worden zonder aanpassingen in de omgeving zijn verder onderverdeeld in EMA categorie 1: hulpmiddelen gericht op obstakel detectie en oriëntatie en EMA categorie 2: navigatiehulpmiddelen. Dertien producten in de eerste en tien producten in de tweede categorie zijn verder gedetailleerd beschreven ten aanzien van hun belangrijkste functionaliteiten, onderdelen, interface en bediening (uitvoer en mogelijkheden voor de invoer van gegevens), en technische specificaties. Voor EMA categorie 1 zijn aanvullend het bereik van detectie, hantering en draagmogelijkheden aangegeven. Voor EMA categorie 2 zijn navigatie modi, verstrekte informatie en verschillende (mogelijkheden om) routes (te maken) opgenomen. Binnen beide categorieën werd een grote diversiteit van producteigenschappen en een duidelijk verschil in de complexiteit van functies vastgesteld.

In Hoofdstuk 3 worden de methode en de resultaten van een systematische review gepresenteerd die uitgevoerd werd om de gerapporteerde effecten en de effectiviteit van EMA te achterhalen zoals deze in de internationale literatuur beschreven zijn. Dertien studies over zes verschillende beschikbare EMA werden geïncludeerd. Twee studies waren gericht op een van de tien navigatie hulpmiddelen (EMA categorie 2). In de overige 11 studies zijn vijf van de 13 verkrijgbare categorie 1 hulpmiddelen voor obstakel detectie en oriëntatie geëvalueerd. In acht studies werd gebruik gemaakt van een experimenteel 'within-subjects' (herhaalde metingen) design of van een 'single subject alternating treatment' design. De overige werden als 'field trial', 'survey' en 'follow-up' studie beschreven. Het merendeel van de studies rapporteert positieve effecten van het gebruik van EMA. Het navigatiesys- 
teem heeft zowel in een experimentele setting als ook bij het navigeren in de wijk een significante verbetering in het bereiken van een bepaalde bestemming laten zien. Vier studies over EMA categorie 1 waarin de mobiliteitsvaardigheden van gebruikers met behulp van een experimenteel design onderzocht zijn, hebben een verbeterde vaardigheid in het vermijden van obstakels en het vinden van herkenningspunten aangetoond, zoals toegenomen reis- en mobiliteitsvaardigheden. In de drie studies waarin tevens de snelheid van verplaatsen gemeten werd, is deze gedaald. In een studie is de snelheid van verplaatsen ten gevolge van een groter bereik van detectie toegenomen. In een andere studie werd geen effect op de mobiliteitsvaardigheden gevonden. De meeste deelnemers hebben, net als de ondervraagden in de surveys en de follow-up studie, hun verplaatsingen buitenshuis als veiliger, aangenamer en minder stressvol ervaren. Tussen $44 \%$ en $100 \%$ van de respondenten gaven aan het EMA nog steeds te gebruiken en voor het grootste gedeelte van de gebruikers was de kwaliteit van reizen en de hoeveelheid reizen toegenomen. Redenen voor niet-gebruik werden niet in verband gebracht met de functionaliteit van de hulpmiddelen, maar met het ontwerp of de vormgeving, persoonlijke omstandigheden, omgevingsfactoren of met gewenning aan de omgeving waarin men zich buitenshuis verplaatst of reist.

De ontwikkeling van een parcours binnenshuis, voor het meten van mobiliteitsvaardigheden in het kader van een gebruiksonderzoek naar EMA, wordt in Hoofdstuk 4 beschreven. Een literatuuronderzoek heeft geleid tot een inventarisatie van eerder gehanteerde onderzoeksmethoden voor het meten van de mobiliteit bij de doelgroep, kritieke factoren en bepalende elementen voor het beoordelen van mobiliteitsvaardigheden en voor de samenstelling van een mobiliteitsparcours. Deze inventarisatie kan ook als instrument gebruikt worden bij het opstellen van een toekomstig parcours. Op basis van deze inventarisatie zijn concrete keuzes gemaakt voor het beoogde gebruiksonderzoek. De keuzes werden bepaald door de geselecteerde hulpmiddelen en hun functionaliteiten, om deze tegen de functionaliteiten van de taststok af te zetten. Daarnaast werden de keuzes ook bepaald door taken die de functionaliteit en werkwijze duidelijk maken en door praktische overwegingen. Op basis hiervan is een quasi-experimenteel onderzoeksdesign gekozen om de mobiliteitsvaardigheden van de deelnemers in een veilige gecontroleerde omgeving binnenshuis vast te stellen. Hierbij werd specifiek bekeken hoeveel tijd zij nodig hadden om het gestandaardiseerde parcours met 21 obstakels af te leggen, wat het 'percentage voorkeursloopsnelheid' was en hoe vaak zich welk soort van negen vooraf gedefinieerde mobiliteitsincidenten voordeed. Een test versie van het mobiliteitsparcours werd uitgezet en vervolgens een pilot verricht. Advies van experts, O\&M specialisten, heeft de inhouds- en indruksvaliditeit bevestigd. De beschreven meetmethode werd in het gebruiksonderzoek toegepast en bleek bruikbaar, uitvoerbaar en voldoende sensitief te zijn om de verschillen in mobiliteitsvaardigheden 
te meten wanneer gebruik gemaakt wordt van een EMA in vergelijking met het gebruik van het gewone mobiliteitshulpmiddel.

Om inzicht te ververwen in de bruikbaarheid en functionaliteit van EMA en hun effecten op mobiliteit, zijn zes systematisch geselecteerde EMA in een gebruiksonderzoek getest.

In de eerste ronde hebben acht personen met een visuele beperking twee EMA gericht op obstakel detectie en oriëntatie geëvalueerd (Hoofdstuk 5) op een gestandaardiseerd parcours binnenshuis zoals beschreven in hoofdstuk 4 . Bij beide EMA zijn veranderingen in mobiliteitsvaardigheden geobserveerd. Het percentage voorkeursloopsnelheid is met de UltraCane (UC) significant gedaald $(38,36 \% \pm 7,72)$ in vergelijking met de taststok $(48,74 \% \pm 6,72)$. Deelnemers hebben zich ook met de Miniguide (MG) in combinatie met een gewoon mobiliteitshulpmiddel langzamer verplaatst $(41,21 \% \pm 12,22)$, echter dit verschil was niet significant. Het aantal mobiliteitsincidenten daalde van $18,4 \pm 5,7$ naar $10,2 \pm 4,2$ (UC) en 8,5 $\pm 3,9$ (MG) en dit verschil was significant voor beide EMA. Deelnemers hebben minder vaak met de taststok en met hun lichaam obstakels aangeraakt, hebben de omgeving minder vaak met handen en voeten afgetast. Ingrepen van de O\&M instructeur waren minder vaak nodig, echter plotselinge veranderingen in de loopsnelheid deden zich vaker voor wanneer een EMA gebruikt werd. De meeste deelnemers waren over het algemeen best tevreden over de EMA zoals bepaald met de D-QUEST. Op groepsniveau is geen significant verschil in de totaalscores gebruikerstevredenheid tussen de UC en de MG gevonden, maar enkele respondenten hadden wel een uitgesproken voorkeur voor een van de hulpmiddelen. Deelnemers hebben zowel voordelige als nadelige aspecten nauwkeurig beschreven. De aanvullende opmerkingen met betrekking tot de functionaliteit en bepaalde kenmerken van beide apparaten laten zien dat individuele eigenschappen en voorkeuren van de gebruiker, maar ook factoren zoals de normaal gebruikte stoklooptechniek, bijkomende beperkingen en (de duur van) training en gewenning een belangrijke rol spelen bij de beoordeling van deze hulpmiddelen.

In de tweede ronde (Hoofdstuk 6) zijn vier EMA gericht op navigatie, namelijk BrailleNote GPS, Trekker, Trekker Breeze en Wayfinder Access, door 18 personen met een visuele beperking geëvalueerd. Elf taken die gekozen zijn om een duidelijk beeld te geven van de werkwijze en de functionaliteit van de apparaten, werden eerst gebruikt voor instructie en training en dienden vervolgens als test situaties. Een belangrijk onderdeel hiervan vormde het afleggen van een onbekende route buitenshuis.

De benodigde tijd voor het verrichten van de taken liet een hoge variabiliteit tussen de deelnemers zien. Op een uitzondering na zijn alle geteste functionaliteiten beter dan voldoende beoordeeld. De "Binnenshuis bekijken van een route" en de "Waar ben ik"-functie van twee apparaten zijn het beste beoordeeld. De gemid- 
delde beoordeling voor alle geteste functionaliteiten middels Nederlandse schoolcijfers lag tussen 7,2 en 8, terwijl de individuele scores per hulpmiddel tussen 6,2 en 9,9 lagen. De antwoorden op de zeven vragen van de D-QUEST laten zien dat de gebruikerstevredenheid met alle aspecten doorgaans beter was dan min of meer tevreden, met uitzondering van twee aspecten van één apparaat; totaalscores op groepsniveau lagen tussen 3,3 en 4,2 per apparaat, terwijl individuele scores tussen 2,3 en de maximum score van 5 lagen. De aanvullende opmerkingen van de deelnemers en de observaties van de proefleider zijn geanalyseerd en hebben duidelijke persoonlijke voorkeuren laten zien wat betreft de bediening en invoer van gegevens, de hoeveelheid en het detailniveau van de verstrekte informatie. Bij het volgen van de route voelden sommige gebruikers zich (zeer) veilig, terwijl andere deelnemers die zich niet veilig voelden met alleen de routebegeleiding door de hulpmiddelen, de verstrekte informatie als ontoereikend beschouwden om een onbekende route zelfstandig af te kunnen leggen. Het idee gereed te zijn voor het gebruik van een navigatiesysteem in termen van oriëntatie- en mobiliteitsvaardigheden en eerder opgedane ervaring in verband met zelfstandig reizen en het gebruik van conventionele hulpmiddelen en technieken voor oriëntatie hebben een belangrijke rol gespeeld bij de evaluatie van de navigatiesystemen.

De resultaten van beide ronden gebruiksonderzoek benadrukken het belang van een zorgvuldige overweging van individuele wensen, behoeften en doelen van de gebruikers en hun verwachtingen met betrekking tot de functionaliteit van EMA voor het proces van advisering en verstrekking van een passend hulpmiddel dat een goede match vormt tussen het persoonsgerelateerde en het productgerelateerde beoogde gebruik.

Hoofdstuk 7 rapporteert over de ontwikkeling van een richtlijn om het proces van advisering van EMA categorie 2 te ondersteunen. Hiervoor zijn, gebaseerd op de eerste twee fases van dit onderzoek, vier stappen van een generieke Nederlandse richtlijn voor de verstrekking van hulpmiddelen, de 'RiFA', specifiek toegepast voor drie op dit moment verkrijgbare navigatiehulpmiddelen: Trekker Breeze, Kapten Mobility en de iPhone met een combinatie van navigatie apps. Het adviesprotocol bestaat uit een inleiding, een handleiding met een nauwkeurige beschrijving van de te volgen procedure, een set van 15 formulieren en vier bijlagen. Het protocol biedt een systematiek voor de stappen Vraagverheldering, Doelbepaling, Opstellen van een Programma van Eisen en Productselectie. Het adviesprotocol is gekoppeld aan een EMA database die door het beschrijven van de verschillende producten in technische en functionele termen op een gestandaardiseerde manier voor onderlinge vergelijkbaarheid zorgt. Samen met een trainingsprotocol voor het aanleren van hulpmiddelgebruik en een werkwijze voor de evaluatie van de effectiviteit van de hulpmiddelverstrekking is het adviesprotocol geïmplementeerd bij de zorgaanbieders Bartiméus en Koninklijke Visio. Beide protocollen worden verankerd in het 
leerplan voor bij- en nascholing van oriëntatie- en mobiliteitsinstructeurs. Een webgebaseerd informatieproduct over EMA voor verschillende doelgroepen wordt momenteel samengesteld.

Hoofdstuk 8 presenteert een methode om reisgedrag en feitelijke verplaatsingen buitenshuis in kaart te brengen als onderdeel van het onderzoek naar effecten van het lange termijn gebruik van EMA categorie 2 (navigatiesystemen). Het bijhouden van een activiteitendagboek (AD) met behulp van toegankelijke, voorgestructureerde formulieren wordt hiervoor gecombineerd met GPS data loggers (DL). Beide onderdelen registreren het totale aantal trips en het aantal trips dat lopend afgelegd is. Het $A D$ heeft een verdere specificatie mogelijk gemaakt van de manier van verplaatsen, het doel van de reis, ondersteuning en hulmiddelen die gebruikt zijn, bekendheid met de route, hoe de persoon zich gevoeld heeft tijdens het afleggen van de route en of het reizen zelfstandig of met begeleiding was. De DL verschaft meer objectieve gegevens omtrent de benodigde tijd, afgelegde afstand, gemiddelde snelheid van verplaatsen, en de maximale, start en eind afstand ten opzichte van het thuisadres. Het op de vereisten van dit onderzoek aangepast softwareprogramma heeft de locatie informatie van de gelogde gegevens buiten beschouwing gelaten. Op deze manier heeft dit programma ongecompliceerde verwerking van de gegevens mogelijk gemaakt en de privacy van de deelnemers beschermd. In totaal hebben 53 personen met een visuele beperking de meetperiode van 14 dagen afgerond. Dit komt overeen met een response van $79,1 \%$. Het totale aantal trips was gemiddeld 70,7 $\pm 33,5$ (AD) en $66,85 \pm 27,26$ (DL). De meeste trips werden lopend afgelegd (63\% AD, 51\%DL), gevolgd door $18 \%$ meerijdend in een auto en $14 \%$ gebruik makend van openbaar vervoer. Bijna een kwart van alle trips werd verricht in verband met het gebruik maken van openbaar vervoer, $17 \%$ voor (recreatief wandelen) of de (geleide)hond uitlaten en bijna 12\% voor IADL. Driekwart van alle trips zijn op een vaste of bekende route afgelegd. In totaal zijn $61 \%$ van alle trips zelfstandig afgelegd. Gemiddeld hebben personen met een geleidehond meer trips gemaakt dan personen met een taststok, gevolgd door personen met een herkenningsstok en personen die (nog) geen gebruik maakten van een mobiliteitshulpmiddel. De gemiddelde totale afstand die lopend afgelegd werd, was $25,58 \pm 20,03 \mathrm{~km}$, terwijl $394,49 \pm 336,9 \mathrm{~km}$ met een ander vervoersmiddel afgelegd werd. De correlatie en overeenkomst van de aspecten die beide instrumenten hebben gemeten was redelijk. Zowel het verzamelen als ook de analyse van gegevens bleek goed uitvoerbaar en de voorgestelde methode bleek geschikt voor een effectiviteitsstudie naar EMA.

Hoofdstuk 9 bevat de belangrijkste bevindingen van de studie. Zij worden bediscussieerd in het licht van theoretische en methodologische overwegingen en er worden aanbevelingen voor de praktijk gegeven. Een belangrijk deel van de aanbevelingen 
voor de praktijk zijn reeds in een implementatie project gerealiseerd. Op basis van de resultaten van de eerste twee fasen van de studie die belangrijke aandachtspunten hebben laten zien die bij de verstrekking van EMA overwogen moeten worden, is een protocol voor de selectie en advisering ontwikkeld. Concepten voor toegankelijke informatieproducten op maat voor gebruikers, professionals en overige belanghebbenden zijn ontwikkeld. Het wordt aanbevolen de systematische benaderingswijze bij de specificatie van alle stappen in het proces van hulpmiddelenverstrekking volgens de RiFA ook bij de overige categorieën van mobiliteitsgerelateerde en overige hulpmiddelen voor personen met een visuele beperking toe te passen. Vervolgonderzoek richt zich op de uitvoering van een lange termijn effectiviteitsstudie volgens de in hoofdstuk 8 beschreven methode in de vorm van een gerandomiseerde, gecontroleerde trial. 